Journal of Business Ethics

\title{
When Employees Retaliate Against Self-Serving Leaders: The Influence of the Ethical Climate \\ --Manuscript Draft--
}

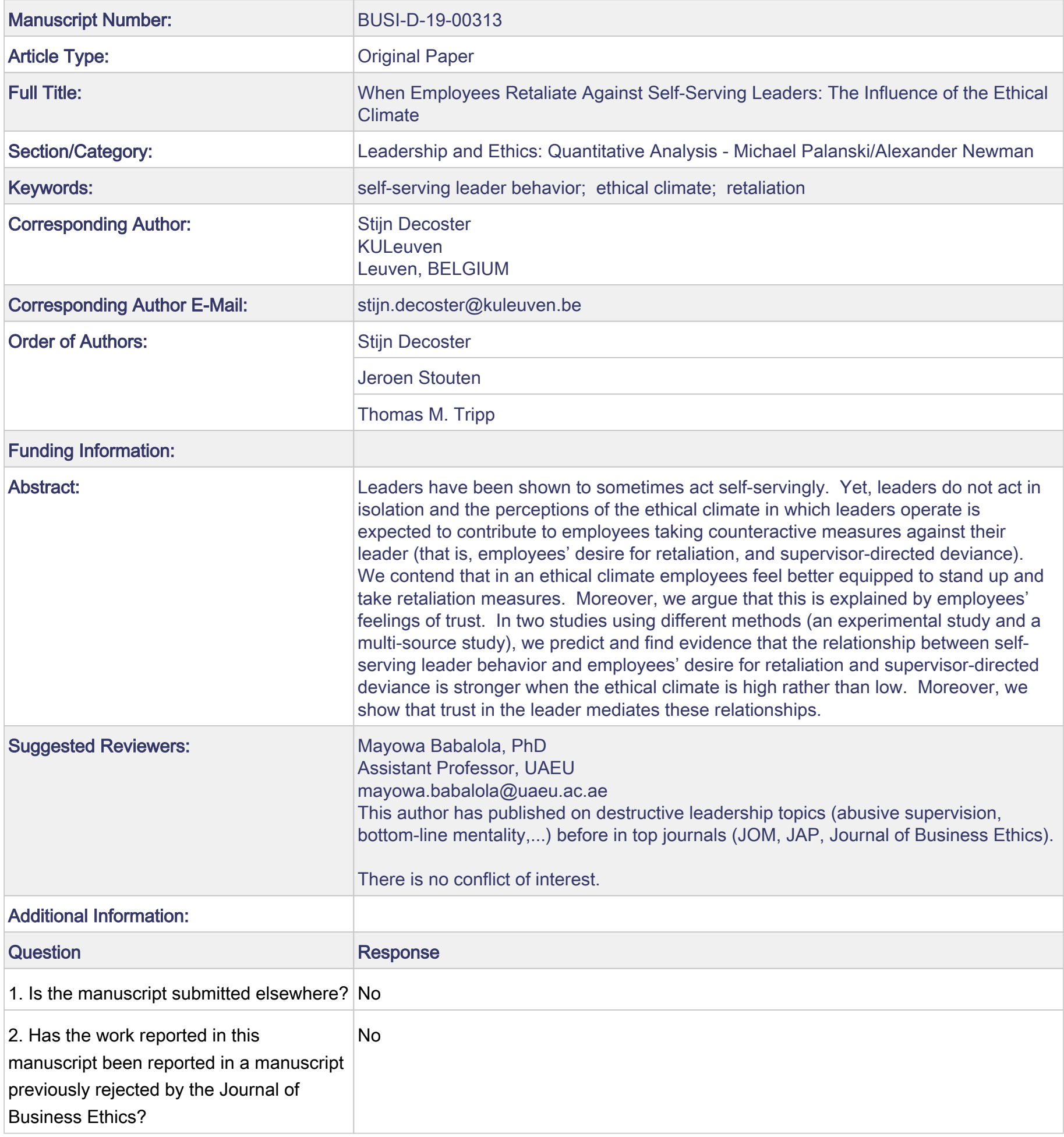


When Employees Retaliate Against Self-Serving Leaders:

The Influence of the Ethical Climate

\author{
Stijn Decoster \\ Zayed University \\ University of Leuven \\ stijn.decoster@zu.ac.ae \\ Jeroen Stouten \\ University of Leuven \\ jeroen.stouten@kuleuven.be
}

Thomas M. Tripp

Washington State University

ttrip@wsu.edu

Correspondence to Stijn Decoster, College of Business, Zayed University, Dubai, email:

stijn.decoster@zu.ac.ae; telephone +971503872220 


\section{Acknowledgments}

We thank Gary Greguras and Michael Bashshur for their thoughtful comments on earlier versions of this paper.

\section{Conflict of Interest}

The authors declare that they have no conflict of interest. 
When Employees Retaliate Against Self-Serving Leaders:

The Influence of the Ethical Climate

21

22

23

24

25

26

27

28

29

30

31

32

33

34

35

36

37

38

39

40

41

42

43

44

45

46

47

48

49

50

51

52

53

54

55

56

57

58

59

60

61

62

63

64

65 


\begin{abstract}
Leaders have been shown to sometimes act self-servingly. Yet, leaders do not act in isolation and the perceptions of the ethical climate in which leaders operate is expected to contribute to employees taking counteractive measures against their leader (that is, employees' desire for retaliation, and supervisor-directed deviance). We contend that in an ethical climate employees feel better equipped to stand up and take retaliation measures. Moreover, we argue that this is explained by employees' feelings of trust. In two studies using different methods (an experimental study and a multi-source study), we predict and find evidence that the relationship between self-serving leader behavior and employees' desire for retaliation and supervisor-directed deviance is stronger when the ethical climate is high rather than low.

Moreover, we show that trust in the leader mediates these relationships.
\end{abstract}

Keywords: self-serving leader behavior, ethical climate, social exchange, social information processing theory, supervisor-directed deviance, desire for retaliation. 


\section{When Employees Retaliate Against Self-Serving Leaders: \\ The Influence of the Organization's Ethical Climate}

Media reports have drawn the attention to self-serving leaders who engage themselves in acts of theft and corruption, thereby benefiting themselves at the expense of the organization. For example, John Thain, former CEO of Merrill Lynch, spent \$ 1.2 Million on redecorating his office while his company was on the brink of bankruptcy (Rus, van Knippenberg, \& Wisse, 2010). More generally, leaders sometimes seem to be willing to misuse corporate funds for their own greed or self-interest (Brown \& Treviño, 2006; Brown, Treviño, \& Harrison, 2005; Haynes, Josefy, \& Hitt, 2015; Kellerman, 2004). Indeed, various organizational scandals indicate that leaders may not always act for the best of the collective interest. For example, Dennis Kozwalski of Tyco and Kenneth Lay of Enron benefited themselves at the expense of their company. More recently, a senior manager of Microsoft was arrested for stealing more than 9 million USD from his organization to pay for an extravagant lifestyle. We define such self-serving leaders as "leaders who place their own well-being and interests above both their followers' needs and the goals of the organization" (Camps, Decoster, \& Stouten, 2012, p. 49).

In spite of these examples, research specifically focusing on self-serving leader behavior is fairly understudied. However, some provisional conclusions can be drawn (e.g., Krasikova, Green, \& LeBreton, 2013; Schyns \& Schilling, 2013). First, previous research supports that employees often respond in a negative way to leaders who behave self-servingly (e.g., Schyns \& Schilling, 2013). Self-serving leaders, for example, reduce employees’ affective commitment, job satisfaction, team creativity, and organizational citizenship behaviors (OCB) (e.g., Decoster, Stouten, \& Tripp, 2014b; Liu, Chiang, Fehr, Xu, \& Wang, 2017; Peng et al., 2018). Moreover, self-serving leader behaviors are also linked to negative outcomes, such as workplace deviance including employees' desire for retaliation and 
supervisor-directed deviance (e.g., Schyns \& Schilling, 2013). Hence, employees sometimes desert.

Yet, the when and why employees may stand up against self-serving leadership is currently not well understood. Here, we aim to examine this more closely and contend that an important aspect of the motivation to retaliate self-serving leadership is how employees perceive the context in which they work as containing signals of what is appropriate or ethical behavior (Kellerman, 2004; Padilla, Hogan, \& Kaiser, 2007). In this research, we examine employees' desire for retaliation and supervisor-directed deviance, and we expect these reactions to depend on the specific context in which the self-serving behavior occurs. For instance, even though employees may react to self-serving leaders, they may remain silent if they do not perceive an ethical climate, that is, if self-serving behavior is deemed to be more 'acceptable' (Stouten, Tripp, Bies, \& De Cremer, in press). Research indeed shows that employees do not necessarily react negatively to leaders who behave self-servingly (Decoster et al., 2014b; Stouten \& Tripp, 2009).

Companies inherently create specific contexts by, for example, signaling and communicating corporate values, which are a marker for employees' behavior with their coworkers but also with other stakeholders. By communicating their corporate values, organizations often aim to foster values of respect, consideration, and maintaining professional standards building a climate of morality and ethics. Such instances nurture employees' perceptions of an ethical climate as entailing norms that guide employees' behaviors (Cullen, Parboteeah, \& Victor, 2003). Therefore, an ethical climate is an important filter through which employees make sense of their work situation: employees' perception of the ethical climate (i.e., their psychological ethical climate) will reflect their ideas about the ethical character of their organization or work unit (Victor \& Cullen, 1987). Despite the 
importance of employees' perceptions of the ethical context, little is known about how ethical employees would be more reactive or less reactive towards the leaders' actions (Brown \& Treviño, 2006; Martinko, Harvey, Brees, \& Mackey, 2013).

In this paper, we argue that employees' perceptions of ethical climate moderate the relation between self-serving leader behavior and supervisor-directed deviance. Specifically, we argue that in a high ethical climate - when strong norms of ethically appropriate behavior exist - a self-serving leader's behavior disconfirms employees' expectations and therefore violates their trust. Because of this trust violation, ironically, we contend that employees will turn to retaliatory mechanisms. Furthermore, we expect that employees' lack of trust and desire for retaliation mediate the relationship with supervisor-directed deviance (Bies \& Tripp, 1996).

This study contributes to the existing literature on several fronts. First, despite the severe impact self-serving leaders can have on the entire organization (e.g., the misuse of corporate funds), the topic of self-serving leaders has not received much attention in the management and psychological literature (for exceptions see Rus et al., 2010a, 2010b, 2012; Williams, 2014; Wisse \& Rus, 2012). Indeed, in contrast to studies contributing to our understanding of abusive supervision (Tepper, Simon, \& Park, 2017), a specific focus on selfserving leader behaviors is still lacking. This is surprising, because as it has been argued, self-serving leader behaviors occur more frequently than the hostile and aggressive behaviors that are related to abusive supervision (Schmid, Verdorfer, \& Peus, 2017).

Second, whereas previous studies on self-serving leader behaviors focused on the emergence of self-serving leaders (Decoster et al., 2014a), or on outcomes such as employees' negative emotions (Camps et al., 2012), organizational commitment (Decoster et al., 2014b), prosocial behavior (Liu et al., 2017), and creativity (Peng et al., 2018), we still know little 
about employees' reactions that are directed towards their leader. Yet, employees' reactions silence as approval of his/her self-serving behavior, thereby reinforcing it and even creating a negative escalation spiral (Bies, 2013; Klaussner, 2014). Therefore, it is important to examine employees' reactions to self-serving leaders.

Third, we add to the ethical climate literature. Although previous research shows that leaders have the opportunity to shape an ethical climate (Mayer, Kuenzi, \& Greenbaum, 2010; Schminke, Ambrose, \& Neubaum, 2005), little research has yet focused on the impact of the ethical climate on employees' reactions towards negative leader behavior. We add to the ethical climate literature by showing that employees' reactions to self-serving leaders depend on the level of the ethical climate. Moreover, we also show that organizational members in an ethical climate do not necessarily refrain from reacting in a deviant way, despite the norm to act ethically. Indeed, we argue that people react more strongly (i.e., more retaliatory) towards leader behavior that is inconsistent with the ethical climate, even though deviant reactions are commonly perceived as negative. That is, we contend that a high ethical climate can facilitate, rather than hinder, employees' retaliation towards their leader.

\section{Self-Serving Behaviors}

Leaders sometimes tend to focus on their own wellbeing without showing much consideration for their employees' needs or for the goals of the organization, for example, when they misuse the organization's budget for personal gain (Wade, O'Reilly, \& Pollock, 2006). In spite of this observation, research that specifically focuses on self-serving leader behavior is fairly understudied. However, many different - partly overlapping - concepts are used for different types of self-serving leadership such as, for example, destructive leadership (Einarsen, Aasland, \& Skogstad, 2007), or narcissistic leadership (Rosenthal \& Pittinsky, 
2006). Though, the construct that received the most attention in the literature is abusive

supervision (Tepper, 2000), which refers to "subordinates' perceptions of the extent to which supervisors engage in the sustained display of hostile verbal and nonverbal behaviors, excluding physical contact” (Tepper, 2000, p. 178). Although self-serving leader behaviors and abusive supervision are positively related to each other (Camps et al., 2012), they are distinct from one another when we compare them along Tepper's (2007) dimensions. First, abusive supervision is directed downwards towards the employees, in contrast to self-serving leadership, which is directed at enhancing one's own wellbeing, without much concern for others' wellbeing (Haynes et al., 2015). Indeed, in contrast to a self-serving leader, who is only focused on satisfying personal interests (the behavior is self-directed), an abusive supervisor usually has clear targets (the behavior is employee-targeted) who are directly and overtly harmed (Peng, Wang, \& Cheng, 2018). Second, while abusive supervision excludes hostile physical behaviors, such behaviors could be part of self-serving leaders' actions when displayed in order to enhance the leader's personal outcomes. Third, whereas abusive supervision is characterized by high hostility, self-serving leader behavior is not necessarily perceived as hostile (e.g., a leader who overloads employees by delegating them additional tasks in an overtly friendly way). Finally, whereas the definition of abusive supervision does not imply a reference to one's intended outcomes, self-serving leaders place their personal goals first.

\section{Employees' Reactions to Self-Serving Leaders}

How would employees react to self-serving leaders? To answer this question, we draw on social exchange theory (Blau, 1964; Gouldner, 1960). Employees perceive their relationship with their leader as a social exchange in which each party seeks to reciprocate the costs and benefits received to maintain balanced contributions. When employees feel their personal interests are being taken care of, they are motivated to reciprocate in a constructive 
way. In contrast, when confronted with a leader who puts his/her own interests first, employees may feel an imbalance between their efforts and the expected benefits, and they may wish to retaliate to restore the balance (Carlsmith, 2002). Hence, social exchange theory, and by extension the norm of reciprocity, suggest that individuals who are harmed reciprocate in a negative way to restore the balance (Blau, 1964; Gouldner, 1960).

We already defined self-serving leaders as leaders who place their own wellbeing and interests above both their followers' needs (Camps et al., 2012). Whether the leader's selfserving behavior actually harms employees or not is theoretically orthogonal to the definition (de Dreu \& Nauta, 2009; Williams, 2014). However, previous research showed that, in general, high concern for one's self-interest correlates with low concern for others and vice versa (Peng et al., 2018). That is, often there is a trade-off between self-interest and the interests of others, which means the self-interested behavior is often at the expense of others (DeCelles, DeRue, Margolis, \& Ceranic, 2012). Indeed, generally, self-serving leadership worsens employees' outcomes and results in harmful, long-term ramifications for the organization (Haynes et al., 2015; Schyns \& Schilling, 2013). This is in line with Williams' (2014) suggestion "that regardless of whether the direct and immediate impact of leaders' behaviors on others is positive, negative, or neutral, leaders who regularly prioritize their own needs and goals ultimately will have a negative long-term net impact on their organization" (p. 1366). In sum, even if the leader's self-serving behavior is not immediately damaging, eventually (i.e., long-term), in most cases it is expected to have a negative impact on employees or the organization (Thoroughgood, Tate, Sawyer, \& Jacobs, 2012).

This reasoning, suggesting that employees will try to reciprocate in a negative way to a leader's self-serving behavior, is in line with previous research showing that individuals often seek revenge against those who harm them, and that they especially direct their responses toward the perceived source of harm, to restore a sense of justice and to prevent 
further acts of mistreatment (Aquino \& Thau, 2009; Bies \& Tripp, 1996; Jones, 2009; Thau,

Bennett, Mitchell, \& Marrs, 2009). More specifically, when employees are harmed by their leader, they are fed with a desire for retaliation (Mitchell \& Ambrose, 2007). We define employees' desire for retaliation as the wish to bring harm upon their leader because of the perceived harm that was caused by the leader (Stuckless \& Goranson, 1992). Because the desire to retaliate is a motivational force that encourages deviant acts (El Akremi, Vandenberghe, \& Camerman, 2010; Jones, 2009), we also expect employees to show supervisor-directed deviance towards a self-serving leader. Supervisor-directed deviance consists of "deviant acts that are directly targeted against the supervisor" (Thau et al., 2009, p. 86), such as acting rudely or publicly embarrassing one's supervisor. These predictions are in line with previous research showing that self-serving types of leader behaviors are linked to employees' supervisor-directed deviance (Hershcovis et al., 2007; Inness et al., 2005; Mayer, Thau, Workman, Van Dijke, \& De Cremer, 2012; Mitchell \& Ambrose, 2007, 2012; Restubog, Scott, Zagenczyk, 2011). To summarize, we predict that self-serving leader behaviors increase employees' desire for retaliation and their supervisor-directed deviance. Formally:

Hypothesis 1a: Self-serving leader behavior will be positively related to employees' desire for retaliation.

Hypothesis $1 \mathrm{~b}$ : Self-serving leader behavior will be positively related to employees’ supervisor-directed deviance.

\section{Trust in the Leader}

Drawing on social exchange theory, we propose that the relation of self-serving leader behavior to employees' supervisor-directed deviance is explained by employees' trust in their 
leader. Trust is an important process in the supervisor-employee relationship and leaders are

Yukl, 1998). Rousseau, Sitkin, Burt, \& Camerer (1998, p. 395) define trust as "a

psychological state comprising the intention to accept vulnerability based upon positive expectations of the intentions or behavior of another." Two components are incorporated in this definition: a person's willingness to accept vulnerability and the expectation for positive outcomes (Colquitt, Scott, \& LePine, 2007). Trust is important because "it is the most direct, economical and effective way for leaders to improve the effectiveness of organizations" (Ding et al., 2012, p. 258).

According to social exchange theory, employees who perceive their relationship with their leader going beyond the standard economic contract expect the leader-employee relationship to operate based on trust, goodwill, and the perception of mutual obligations (Blau, 1964; Dirks \& Ferrin, 2002). Leadership interactions that are characterized by these higher-quality exchanges are linked to employees' trust and support (e.g., Dirks \& Ferrin, 2002; Liden \& Graen, 1980; Podsakoff et al., 1990). For example, employees show more trust in their leader when (s)he demonstrates interest in his/her employees' ideas (De Cremer, van Dijke, Schminke, De Schutter, \& Stouten, 2018; Korsgaard, Schweiger, \& Sapienza, 1995) and has benevolent motives towards the employees (Mayer, Davis, \& Schoorman, 1995). In contrast, when confronted with a leader who is perceived to be less concerned in his/her employees' goals and interests (i.e., a self-serving leader), employees question the leader's willingness to engage in a mutually beneficial social exchange. That is, when leaders act in a self-serving way, employees are unsure whether they can expect positive exchanges, and - following the definition of trust - they will have less trust in the leader. Indeed, as the leader's self-serving behavior is not necessarily detrimental for employees, his/her behavior will leave employees with additional uncertainty whether they can trust the leader or not. 
This is in line with Camps and colleagues (2012), who argued that the extent to which leaders procedural justice that is essential in evaluating whether a leader's decision-making process can be trusted or not (Leventhal, 1980). For example, if employees feel that the leader makes biased decisions in favor of his/her self-interest, they are less likely to trust the leader in comparison with a leader who makes unbiased decisions.

Social exchange theory suggests that for leaders who do not fulfill their end of the contract, employees may compensate by getting even. That is, when employees do not receive their end of the bargain, they will consider seeking a "rebalance" of the contract by, for example, reducing their inputs (e.g., work less hard; "let down" the supervisor), or increasing their outcomes (e.g., stealing office supplies). These theoretical arguments are in line with previous research showing that self-serving leader behaviors negatively relate to employees' trust in their leader (Ding et al., 2012; Duffy \& Ferrier, 2003; Schyns \& Schilling, 2013). In sum, we assume that self-serving leader behavior is related to lower levels of employees' trust.

According to social exchange theory, when employees trust their leaders, they likely have a history of successful exchanges (Blau, 1964). Trust also creates expectations about employees' and leaders' future behaviors. More specifically, both parties expect they can keep operating on the basis of trust, goodwill, and the perception of mutual obligation (Blau, 1964). When employees trust their leader, they are motivated to preserve the relationship with their leader as this relationship is accompanied by expectations of possible future benefits. In contrast, employees may become upset when they perceive a loss of trust toward their leader. Employees who do not trust their leader are less likely to continue the relationship because there is a lack of positive expectations and no sense of obligation. Moreover, a loss of trust can amplify the desire for retaliation (Bies \& Tripp, 1996). This is 
in line with a meta-analysis (Colquitt et al., 2007) examining the impact of trust on task analysis showed that individuals who trust their leader show less counterproductive behaviors.

Moreover, when employees experience low trust in their leader and they witness subsequent negative leader behavior of ambiguous intent, employees do not attribute benign motives for the negative behavior (Hollander, 1958). That is, low levels of trust create a form of paranoia, whereby employees are biased to attribute intentional explanations for the leader's every harmful mistake, such as the leader harmed others on purpose, not by accident (Kramer, 1994). As research on revenge shows, inference of harmdoers' motives matter, such that the greater the perceived intentionality for the harm, the higher the desire for retaliation (Crossley, 2009; Gregoire, Laufer, \& Tripp, 2010; Joireman, Gregoire, Devezer, \& Tripp, 2013; Tripp \& Bies, 2009).

Given that self-serving leader behavior is expected to be negatively related to employees' trust, and that employees' trust is expected to be negatively related to employees' desire for retaliation, we argue that employees' trust mediates the relation between selfserving leader behavior and desire for retaliation.

Hypothesis 2: Trust in the leader will mediate the relationship between self-serving leader behavior and employees' desire for retaliation.

\section{Ethical Climate}

The ethical climate refers to the "prevailing perceptions of typical organizational practices and procedures that have ethical content" (Victor \& Cullen, 1988, pp. 101). The ethical climate functions as a psychological mechanism through which ethical issues are perceived and acted upon and it provides understanding to what behaviors are valued and 
acceptable, which helps individuals to determine the appropriate ways to behave (Martin \& inclined to adhere to ethical guidelines and to behave in an ethical way. In contrast, in a low ethical climate, ethical practices are less valued. Ethical climates are typically related to positive outcomes such as job satisfaction, organizational commitment, and more ethical decision-making, whereas low ethical climates are related to negative outcomes such as turnover intentions and unethical behaviors (e.g., Cullen et al., 2003; Martin \& Cullen, 2006; Wimbush \& Shepard, 1994; for an overview, see Mayer, Kuenzi, \& Greenbaum, 2009). Social information processing theory (Salancik \& Pfeffer, 1978) helps us explain how ethical climates shape expectations and people's behavior. Social information processing theory states that individuals adapt their attitudes and behaviors to their social context (see also Treviño, 1986). That is, individuals search in their environment for cues to interpret events and to find appropriate ways to behave. More specifically, the organizational environment provides information about norms for appropriate and acceptable conduct. Indeed, the organizational context can influence an individual's expectations about which behaviors to expect and it helps the individual to focus his or her attention on certain information (Mawritz et al., 2012). Therefore, we argue that the ethical climate provides organizational members with information of which behaviors are acceptable (i.e., climaterelevant behavior), and that it may influence employees' reactions to their leader's selfserving behavior.

More specifically, a low ethical climate creates a context that does not discourage deviant or self-serving behavior, even to the possible detriment of others (Simha \& Cullen, 2012; Wimbush \& Shepard, 1994). In other words, a low ethical climate may legitimize a leader's self-serving behavior (Cullen et al., 2003). Therefore, employees are expected to 
react less negatively to a self-serving leader as his/her behavior is consistent with what the climate signals as appropriate (Burgoon, 1993; Rodgers, Sauer, \& Proell, 2012).

On the other hand, in a high ethical climate, self-serving behavior is counternormative and inappropriate (Wimbush \& Shepard, 1994). If employees perceive the ethical climate to be high, employees consider that their leader's self-serving behavior may violate organizational norms (Skarlicki, Barclay, \& Pugh, 2008). If so, then in a high ethical climate, a leader's self-serving behavior is more salient and thus will have a stronger impact on employees' reactions. This reasoning is in line with norm-focus theory, which states that the presence of social norms (i.e., when the ethical climate is high) heightens individuals' awareness of these norms, and that individuals tend to act in accordance with them (Cialdini, Reno, \& Kallgren, 1990; Schultz, Nolan, Cialdini, Goldstein, \& Griskevicius, 2007). Moreover, ethical norms will make organizational members more sensitive to violations of these norms. For example, when a leader acts self-servingly in a high ethical climate, his/her behavior violates employees' expectations making the leader's behavior unpredictable, hence lowering employees' trust in comparison with a low self-serving leader (Colquitt et al., 2007; Rodgers et al., 2012). Indeed, because a self-serving leader fails to enforce the expectations that are evoked by a high ethical climate, employees' trust will be diminished (Burke et al., 2007). In sum, we predict that especially in a high ethical climate (as opposed to a low ethical climate) self-serving leader behavior (in comparison with low self-serving leader behavior) will be related to lower levels of employees' trust.

Hypothesis 3: The relationship between self-serving leader behavior and employees' trust is moderated by ethical climate such that the relationship is stronger in a high ethical climate than in a low ethical climate. 
We argued above that trust in the leader is expected to mediate the relationship between self-serving leader behavior and employees' desire for retaliation (Hypothesis 2). Following this, we expect that the strength of this mediation will vary over different levels of the ethical climate. That is, because of a lack of trust, employees are more inclined to desire retaliation and to enact deviance when they are confronted with a self-serving leader in a high ethical climate (Thau et al., 2007). This reasoning is in line with previous studies showing that when an individual observes another individual failing to abide by the prevailing norms, the observer is expected to react to this inappropriate behavior, especially when the ethicality of the situation is emphasized more (Barclay, Whiteside, \& Aquino, 2014; Greenbaum, Mawritz, Mayer, \& Priesemuth, 2013). More specifically, we propose that the negative relationship between self-serving leader behavior and employees' trust - which will lead to higher levels of desire for retaliation and supervisor-directed deviance - will be stronger when ethical climate is high, rather than low. Thus, we expect that the relationship between selfserving leader behavior and employees' desire for retaliation, as well as their supervisordirected deviance, through trust, is moderated by ethical climate such that these relationships are stronger in a high ethical climate than in a low ethical climate.

Hypothesis 4a: Ethical climate will moderate the indirect effect of self-serving leader behavior on employees' desire for retaliation through trust.

Hypothesis 4b: Ethical climate will moderate the indirect effect of self-serving leader behavior on employees' supervisor-directed deviance through trust.

We tested these hypotheses in two studies using different research designs. We relied on an experimental scenario study to be able to infer causality and increase internal validity, then conducted a cross-sectional field study to ensure mundane realism. Such a mixed- 
method approach has been argued to provide more reliable results. Study 1 is a scenario experiment, which creates the advantage of controlling the predictors of interest, thereby making it possible to draw causal inferences (Greenberg \& Folger, 1988). Given the nature of this design, in this study we mainly focused on testing the hypotheses concerned with participants' desire for retaliation, as it is less feasible to test for deviant behavior. In Study 2, we aimed to replicate and expand the findings of Study 1 to a different context with a different sample. More specifically, Study 2 is a field study in an organizational setting, thereby enhancing the external validity and generalizability of the results (Greenberg \& Tomlinson, 2004). We used a multi-source design, a method where ratings from multiple sources are assessed. That is, both employees and their coworkers responded to different measures. This procedure is often used to reduce same-source method bias (Podsakoff, MacKenzie, Lee, \& Podsakoff, 2003). Informed consent was obtained from all individual participants included in both studies.

\section{Study 1}

\section{Method}

\section{Participants and Design}

One hundred and seven undergraduate university students (35 men and 70 women, 2 participants failed to report their gender) participated voluntarily in the study. Participants were assured that their answers would be processed anonymously. Participants' mean age was 20.51 years $(S D=2.92)$ and they had an average work experience of 9.17 months $(S D=$ 10.98). They were randomly assigned to a 2 (ethical climate: low vs. high) x 2 (self-serving leader behavior: low vs. high) between-subjects factorial design.

\section{Procedure}

Participants were welcomed in the laboratory and seated in separate cubicles. They were given a scenario and were asked to place themselves as much as possible in the given 
situation. In this scenario, participants learned that they were a follower in a team of member of one of these teams. To perform your job, you work closely together with the other employees of your team, as well as with the leader of your team."

After this introduction, the ethical climate was manipulated. The descriptions of the ethical climate were based on Mayer et al.'s (2015) ethical climate questionnaire. Participants in the high (low) ethical climate condition read the following message:

"In this organization, people are (not) very concerned to act in an ethical way. When decisions are made, organizational members (do not) continually strive to maintain high ethical standards. There is (not) a strong focus on respecting the ethical standards. Indeed, success in this organization is defined not just by the results, but also by the way these results are obtained (is only defined by the results, not by the way these results are obtained)."

After the ethical climate manipulation, we introduced the leader-type manipulation. In the high self-serving leader condition, participants read:

"It turns out that the leader behaves in a self-serving way. The leader thinks (s)he is very important and (s)he does not show consideration for his/her employees."

In the low self-serving leader condition, participants read:

"It turns out that the leader does not behave in a self-serving way. The leader does not think (s)he is very important and (s)he shows consideration for his/her employees."

\section{Measures}

After participants read the situation, they were asked to rate their trust in the leader and to what extent they would retaliate against the leader. All items were completed on a 7point Likert scale ranging from 1 (= strongly disagree) to 7 (= strongly agree). 
Manipulation checks. Our ethical climate manipulation was checked with the

following items: "The members of this organization try to work as ethically as possible," "The employees of this organization strive to maintain high ethical standards," and "Success in this organization is defined not just by the results, but also the way they are obtained" (Cronbach`s $\alpha=.97)$.

We checked the self-serving leader manipulation with these items: "The leader is selfish and thinks (s)he is very important" and "The leader does not show consideration for others, only for him/herself" (Cronbach's $\alpha=.96)$.

Trust. Employees' trust in their leader was measured with three items (Brockner et al., 1997). Example items are "I can trust my supervisor to do what is good for me" and "I trust my leader to treat me fairly" (Cronbach's $\alpha=.96)$.

Desire for retaliation. Desire for retaliation was assessed with Grégoire and Fisher's (2006) six-item scale. We modified the scale to have the leader, rather than the organization, as the referent for the scale. Example items are "I want to get even with my leader" and "I want to punish the leader in some way" (Cronbach's $\alpha=.94)$.

\section{Results}

Manipulation Checks. A 2 x 2 ANOVA on the manipulation check for ethical climate revealed that high ethical climates were rated as more ethical $(M=6.25, S D=0.61)$ than low ethical climates $(M=1.43, S D=0.50), F(1,103)=1966.15, p<.001, \eta^{2}=.95$. No other effects were significant.

A $2 \times 2$ ANOVA on the manipulation check for self-serving leaders revealed that high self-serving leaders were rated as more self-serving $(M=6.23, S D=0.66)$ than low selfserving leaders $(M=2.30, S D=1.32), F(1,103)=393.11, p<.001, \eta^{2}=.79$. No other effects were significant. 
Desire for Retaliation. A 2 × 2 ANOVA yielded a significant main effect of self-

serving leaders, $F(1,103)=66.31, p<.001, \eta^{2}=.39$. Specifically, participants showed more desire for retaliation in the high self-serving leader condition $(M=3.44, S D=1.38)$ than in the low self-serving leader condition $(M=1.63, S D=0.94)$. These results support Hypothesis 1a. The analysis also yielded a significant interaction effect of self-serving leaders and ethical climate, $F(1,103)=9.79, p<.01, \eta^{2}=.09$. This interaction effect showed that in the high ethical climate condition participants showed more desire to retaliate to high self-serving leaders $(M=3.82, S D=1.49)$ than to low self-serving leaders $(M=1.34, S D=0.45), F(1$, 103) $=64.09, p<.001, \eta^{2}=.36$. Also, in the low ethical climate condition participants showed more desire to retaliate to high self-serving leaders $(M=3.02, S D=1.13)$ than to low self-serving leaders $(M=1.92, S D=1.18), F(1,103)=12.46, p<.01, \eta^{2}=.07$, however the effect was less pronounced than in the high ethical climate condition (see effect sizes). In sum, these results show that the relationship between self-serving leader behavior and employees' desire for retaliation is moderated by ethical climate such that the relation is stronger in a high ethical climate than in a low ethical climate.

Trust. A 2 x 2 ANOVA yielded a significant main effect of self-serving leaders, $F(1$, $103)=96.39, p<.001, \eta^{2}=.48$, as well as for ethical climate, $F(1,103)=22.54, p<.001, \eta^{2}$ $=.18$. Participants showed lower levels of trust in the high self-serving leader condition $(M=$ $2.41, S D=1.11)$ than in the low self-serving leader condition $(M=4.62, S D=1.63)$. We also found that participants showed lower levels of trust when the ethical climate was low $(M=$ $2.99, S D=1.41)$ rather than high $(M=4.00, S D=1.95)$. The analysis also yielded a significant interaction effect of self-serving leadership and ethical climate, $F(1,103)=21.75$, $p<.001, \eta^{2}=.17$. This interaction effect showed that in the high ethical climate condition participants showed lower levels of trust to high self-serving leaders $(M=2.42, S D=1.23)$ than to low self-serving leaders $(M=5.71, S D=0.79), F(1,103)=105.78, p<.001, \eta^{2}=.44$. 
Also, in the low ethical climate condition participants showed lower levels of trust to high self-serving leaders $(M=2.40, S D=0.98)$ than to low self-serving leaders $(M=3.57, S D=$ $1.54), F(1,103)=13.17, p<.001, \eta^{2}=.05$, however the effect was less pronounced than in the high ethical climate condition (see effect sizes). These results support Hypothesis 3.

Mediational analyses. We first regressed desire for retaliation on trust. As predicted, trust in the leader was negatively related with employees' desire for retaliation $(\beta=-.57, p<$ $.001)$. Trust in the leader explained a significant proportion of variance in employees' desire for retaliation, $R^{2}=.47, F(1,105)=91.29, p<.001$.

We used bootstrap procedures (5000 replications) described by Hayes (2018) to examine whether trust in the leader mediated the relation between self-serving leaders and employees' desire for retaliation. Bootstrapping treats the sample as a population and then resamples with replacement and computes relevant statistics for each replacement sample (Preacher \& Hayes, 2008). Results showed that trust mediates the relationship between selfserving leaders and desire for retaliation (95\% CI [0.542, 1.355]). These results support Hypothesis 2.

Results above already revealed an interaction effect of self-serving leaders and ethical climate on desire for retaliation, providing evidence for the direct effect. The results of our moderated-mediation predictions (Hayes, 2018) showed that the indirect effect of self-serving leaders on desire for retaliation through trust was more pronounced in high ethical climates than in low ethical climates (Table 1). These findings support Hypothesis 4a.

In sum, Study 1 showed that employees displayed lower levels of trust and higher levels of desire for retaliation towards self-serving leaders (relative to low self-serving leaders), but especially in a high ethical climate. We conducted this scenario experiment to make it possible to draw causal inferences. However, we also conducted a second study in a field setting to enhance mundane realism and to replicate the findings of the first study. 
Moreover, in this study, we aimed to extend the results of Study 1 to an organizational context, and with desire for retaliation as the underlying mechanism for supervisor-directed deviance. As a result, in Study 2, we also test the following hypothesis:

\author{
Hypothesis 5: Ethical climate will moderate the serially mediated relationship between \\ self-serving leader behavior and employees' supervisor-directed \\ deviance, such that the relationship is stronger in a high ethical climate \\ than in a low ethical climate.
}

\title{
Study 2
}

\section{Method}

\section{Participants and procedure}

Participants were recruited from a variety of different organizations in Belgium, including manufacturing, government, education, technology, and financial organizations. Organizations that agreed to participate provided the researchers with the email addresses of the focal employees. Researchers sent out email invitations via their network of organizations to the focal employees and requested their participation. More specifically, 203 employees were instructed to visit a website to complete a survey, and to send an electronic survey link to one coworker who was familiar with their work. Participation was completely voluntary, and participants were assured that the answers would be processed anonymously (data were matched by using a specific code for each dyad). In no case did a coworker participate with respect to more than one focal employee. Therefore, all dyads were independent of one another. One-hundred fourteen fully matched surveys were returned, yielding an overall response rate of 56.2 percent. One-hundred and eight of the 114 dyads responded to all variables of interest, resulting in a final sample size of 108 dyads. 
Focal employees' (50.9 percent were male) mean age was 36.3 years $(S D=10.45)$.

Employees had an average job tenure of 6.5 years $(S D=6.36)$. Of the employees, $44.4 \%$ only completed high school, $26.9 \%$ had a bachelor's degree, and $28.7 \%$ had a master's degree.

Coworkers (45.4 percent were male) had an average age of 39.1 years $(S D=10.76)$. Of the coworkers, $42.5 \%$ only completed high school, $30.6 \%$ had a bachelor's degree, and 26.9 $\%$ had a master's degree. On average coworkers had a job tenure of 6.9 years $(S D=8.25)$.

\section{Measures}

Employees completed measures of self-serving leadership, trust in their leader, and desire for retaliation. Coworkers reported measures of the ethical climate and employees' supervisor-directed deviance. All items were completed on a 5-point Likert scale ranging from 1 (= never/strongly disagree) to 5 (= very often/strongly agree).

Self-Serving Leadership. Self-serving leadership was assessed with four items (Camps et al., 2012). Example items are "My supervisor is selfish and thinks (s)he is very important" and "My supervisor does not show consideration for his/her employees, only for him/herself" (Cronbach's $\alpha=.87)$.

Desire for retaliation. Desire for retaliation was assessed with Grégoire and Fisher's (2006) scale, as in Study 1 (Cronbach's $\alpha=.94)$.

Supervisor-directed deviance. Employees' supervisor-directed deviance was measured with seven items from Mitchell and Ambrose (2007). An example item is "My coworker publicly embarrassed my supervisor" and "My coworker acted rudely toward my supervisor" (Cronbach's $\alpha=.93$ ). We opted for a non-self-report measure of supervisordirected deviance because employees may feel pressured to not report their own deviance (see also Liu, Kwan, Wu, \& Wu, 2010; Stewart, Bing, Davison, Woehr, \& McIntyre, 2009). A recent meta-analysis showed that the use of other-reports of deviance is a viable alternative to self-ratings (Berry, Carpenter, \& Barratt, 2012). Moreover, we opted to assess supervisor- 
directed deviance from the coworker's rather than the leader's perspective. Indeed, in this case coworker ratings are preferred over leader ratings of supervisor-directed deviance as exploring relationships between employee-reported self-serving leadership and leaderreported evaluations of supervisor-directed deviance may imply assessing the same construct from different perspectives (see Tepper, Simon, \& Park, 2017 for a similar rationale).

Trust. Trust was assessed with the trust scale we used in the first study (Brockner et al., 1997). Cronbach's $\alpha=.94$.

Ethical climate. The ethical climate was assessed with six items (Mayer et al., 2015). Generally, the ethical climate literature focuses on exploring the effects of ethical climates at the work group (Kuenzi \& Schminke, 2009). Therefore, our items also refer to the work group. Given that we are particularly interested in exchange relations of individual employees and their leader, we focus on individual perceptions of ethical climate. An additional argument for such an approach is showing that employees have a strong agreement about perceptions of the ethical climate (e.g., Mayer et al., 2010; Schminke et al., 2005), so we feel confident that measuring the ethical climate from the co-worker's perspective is appropriate. This approach is in line with previous studies that used single team member's measures of ethical climate (e.g., Schwepker, 2001). Example items are "In this work group, employees continually strive to maintain high ethical standards" and "In this work group, employees have a lot of skill in recognizing ethical issues" (Cronbach's $\alpha=.91$ ).

Control Variables. Based on the literature, we identified three demographic variables that could covary with our criterion variables and that should be controlled for (Becker, 2005). These variables were employees' age, gender, and job tenure, which have been found to be related to trust and deviant reactions to the supervisor (e.g., Jones, 2009; Lewicki \& Bunker, 1996).

\section{Results}


Means, standard deviations, and intercorrelations are presented in Table 2. We analyzed the data by conducting hierarchical regression analyses (see Table 3). In step 1 of the regression analyses, we entered the demographic variables age, gender, and job tenure. In step 2, we entered self-serving leadership and the ethical climate. In step 3, we entered the interactive relationship between self-serving leadership and ethical climate and the dependent variables of interest: employees' trust, desire for retaliation and supervisor-directed deviance. We mean centered the independent variables before conducting the analyses (Aiken \& West, 1991). Because the control variables did not alter our findings, we followed Carlson and Wu's (2012) recommendations and reported the results that were obtained without the control variables (see also Becker, 2005; Spector \& Brannick, 2011).

The first regression analysis showed that self-serving leadership was positively related to desire for retaliation $(\beta=.43, p<.001)$. Self-serving leadership accounted for 19 percent of the variance in employees' desire for retaliation, $R^{2}=.19, F(1,106)=24.362, p<.001$. These findings support Hypothesis 1a.

Regression analyses also showed that self-serving leadership was positively related to supervisor-directed deviance $(\beta=.25, p<.01)$. Self-serving leadership explained a significant proportion of variance in supervisor-directed deviance, $R^{2}=.06, F(1,106)=7.18, p$ $<.01$. These findings support Hypothesis $1 \mathrm{~b}$.

To test whether trust mediated the relationship between self-serving leadership and employees' desire for retaliation and supervisor-directed deviance, we relied on the same bootstrap procedure we used in Study 1 (Hayes, 2018). Bootstrap confidence intervals showed that trust in the leader indeed mediates the relationship between self-serving leadership and our two outcomes of interest (Table 4). These results support Hypothesis 2.

Next, hierarchical regression analysis revealed that trust showed a significant interaction effect of self-serving leadership and ethical climate $(\beta=-.33, p<.001)$. We 
conducted simple slopes analysis to further analyze this interaction (Aiken \& West, 1991).

Figure 1 shows the pattern of results. In a high ethical climate, self-serving leadership was more negatively related to trust $(b=-1.01, p<.001)$, than in a low ethical climate $(b=-.30, p$ $<.05)$. The results show that self-serving leadership has a stronger negative relationship with employees' trust in a high ethical climate, rather than in a low ethical climate. These results support Hypothesis 3.

Regression analysis also showed that the interaction between self-serving leadership and ethical climate for employees' desire for retaliation was significant $(\beta=.21, p<.05)$. Simple slopes analyses showed that in a high ethical climate, self-serving leadership was related to desire for retaliation $(b=.52, p<.001)$. In contrast, in low ethical climate, no significant relation between self-serving leadership and desire for retaliation was found $(b$ $=.19, p=.06)$. In sum, results show that self-serving leadership is more related to desire for retaliation in high rather than low ethical climates.

Next, the interaction between self-serving leadership and ethical climate for employees' supervisor-directed deviance was also significant $(\beta=.23, p<.05)$. Simple slopes analyses showed that when the ethical climate was high, self-serving leadership was related to supervisor-directed deviance $(b=.40, p<.001)$. In contrast, when the ethical climate was low, no significant relation between self-serving leadership and supervisordirected deviance was found $(b=.02, p=.89)$. In sum, results show that self-serving leadership is more related to supervisor-directed deviance in high rather than low ethical climates.

Further, as also shown in Table 3, trust was negatively associated with desire for retaliation $(\beta=-.44, p<.001)$ and supervisor-directed deviance $(\beta=-.50, p<.001)$ when controlling for self-serving leadership and ethical climate. The cross-product term between self-serving leadership and ethical climate was not related to both outcomes when trust was 
included in the regression model, which suggests moderated mediation. To further verify our moderated-mediation predictions, we used bootstrap procedures (5000 replications) advocated by Hayes (2018). We examined the conditional indirect effect of self-serving leadership on desire for retaliation and supervisor-directed deviance (through trust) for low and high ethical climates. We used Process 3.1 to calculate the index of moderated mediation (Hayes, 2018). The $95 \%$ bootstrapped confidence interval of this index did not include zero, which indicates that the indirect effect differs across levels of ethical climate. More specifically, bootstrap confidence intervals showed that the indirect and positive effect of self-serving leadership on desire for retaliation and supervisor-directed deviance through trust was more pronounced in high ethical climates than in low ethical climates (Table 5). Taken together, results of the moderated mediation analysis show that trust is a significant mediator of the relationship between self-serving leadership and desire for retaliation, as well as supervisor-directed deviance, but especially in a high ethical climate. These findings support Hypothesis 4a and 4b.

Finally, we also examined the full model, that is, the conditional indirect effect of selfserving leadership on supervisor-directed deviance (through trust and desire for retaliation) for low and high ethical climates (Hayes, 2018). The results showed that the $95 \%$ bootstrapped confidence interval of the moderated mediation index did not include zero, and that ethical climate moderates the indirect effect of self-serving leadership on employees' supervisor-directed deviance through trust and desire for retaliation. More specifically, the indirect effect of self-serving leadership on supervisor-directed deviance through trust and desire for retaliation was more pronounced in high ethical climates, compared to low ethical climates (Table 6). These findings support Hypothesis 5.

In sum, the second study shows that ethical climate and self-serving leadership interact such that self-serving leadership leads to decreased trust and increased desire for 
retaliation and supervisor-directed deviance, but especially in a high ethical climate.

Therefore, the findings of Study 2 are consistent with the findings of Study 1 .

\section{General Discussion}

Despite the detrimental effects self-serving leaders have on employees and the organization, our research found that there are occasions where employees do not react severely to self-serving leaders (see also Stouten \& Tripp, 2009), especially when employees perceive the ethical climate to be low. Conversely, other contexts, such as high ethical climates, more easily trigger negative reactions to self-serving behaviors. Specifically, our results showed that when the ethical climate is high rather than low, employees retaliate more against self-serving leaders with supervisor-directed deviance. Moreover, we showed that employees' trust and their desire for retaliation are the underlying mechanisms that explain this relationship.

This research contributes to the literature in several ways. First, it focuses on selfserving leader behaviors, which have received less attention in the management and psychological literature compared to other negative leadership behaviors, such as abusive supervision (for exceptions see Rus et al., 2010a, 2010b, 2012; Williams, 2014; Wisse \& Rus, 2012). This is quite surprising, as it has been argued that self-serving leader behaviors occur more frequently than the hostile and aggressive behaviors that are related to abusive supervision (Schmid et al., 2017).

Second, previous research on self-serving leader behavior focused on its emergence, as well as on the negative consequences for employees and the organization (Camps et al., 2012; Decoster et al., 2014a; Rus et al., 2010; Rus, van Knippenberg, \& Wisse, 2012). We contribute to this important line of research by adding employees' reactions towards such leaders, and by showing that contextual factors impact the consequences of self-serving leader behavior. 
Third, we also add to the ethical climate literature. Previous research showed that

ethical climates are related to positive outcomes and - more importantly - that such climates weaken the relationship between negative antecedents and deviant outcomes (e.g., Chen, Chen, \& Liu, 2013). Yet, we show that an ethical climate also can enable, rather than hinder, negative outcomes, such as employees' retaliation towards their leader, which seems surprising. After all, previous research showed that ethical climate weakens employees' deviance (Chen et al., 2013), but we show that a high ethical climate strengthens deviance.

Fourth, to date, research has focused on the negative effects of workplace deviance (e.g., Robinson \& Bennett, 1995). However, we argue that supervisor-directed deviance which is a form of workplace deviance directly targeted at the supervisor - might also have beneficial consequences for the organization, because employees might use these behaviors to signal their dissatisfaction and to redress the leader's wrongdoing (see also Kelloway, Francis, Prosser, \& Cameron, 2010). Indeed, although committing acts of supervisor-directed deviance can be viewed as breaking organizational rules, employees sometimes may break these rules in the best interest of the organization. In fact, supervisor-directed deviance may be a means to "righting a wrong" (Bies \& Tripp, 1996) and to "standing up" to the supervisor. Such behaviors, where organizational members violate rules with the intention of promoting the welfare of the organization, are generally described as pro-social rule breaking or constructive deviance (Dahling, Chau, Mayer, \& Gregory, 2012; Morrison, 2006; Vadera, Pratt, Mishra, 2013). Employees might perform acts of supervisor-directed deviance because "doing so is normative and just" (Tepper et al., 2009, pp. 164-165). Because supervisordirected deviance might inhibit further acts of self-serving behavior, these behaviors might contribute to the wellbeing of the organization (Bies \& Tripp, 2001; Vadera, Pratt, \& Mishra, 2013). Indeed, supervisor-directed deviance can be viewed as a form of protest where 
employees attempt to draw attention to the leader's behavior (Kelloway, Fancis, Prosser, \& Cameron, 2010).

Although it has been suggested that employees sometimes refrain from pro-social rule breaking, such as supervisor-directed deviance, out of fear for counter retaliation (Vadera et al., 2013), this might depend on the specific context. For example, in a high ethical climate, employees may feel they have more power to react to self-serving leaders than in a low ethical climate. Indeed, because organizational members who violate the ethical codes (e.g., self-serving leaders) will be disciplined, an ethical environment is expected to protect members who signal such behavior. We suggest that future research could address when and why employees show supervisor-directed deviance towards a self-serving leader. Moreover, future research may examine in which situations employees will direct their deviance to the organization instead of to the leader.

On the one hand, in organizations with a high ethical climate, one may expect to see supervisor-directed deviance - rather than organizational deviance - because employees might perceive the self-serving leader as having violated organizational norms, and retaliation is an attempt to restore the order (Christian, Christian, Garza, \& Ellis, 2012; Skarlicki, Barclay, \& Pugh, 2008). Indeed, previous research showed that individuals tend to direct their deviance toward the source that is held responsible for the perceived harm to restore the situation (Jones, 2009). On the other hand, in organizations with a low ethical climate, one may expect spillover effects because in such situations, employees might hold the organization partly responsible for the leader's behavior (Tepper, Lambert, Henle, Giacalone, \& Duffy, 2008). That is, supervisors are viewed as agents of the organization and their behaviors are perceived as a representation of the organization itself (Eisenberger, Stinglhamber, Vandenberghe, Sucharski, \& Rhoades, 2002). Moreover, employees may perceive that the organization does not intervene to protect them (Burris, Detert, \& Chiaburu, 
2008). Therefore, employees may feel they are not valued by their organization and as a result they may engage in organizational deviance (Lian, Ferris, \& Brown, 2012). Moreover, in an organization with a low ethical climate, employees may feel they do not have the power to retaliate to the leader and they might fear further harm from the leader (Mitchell \& Ambrose, 2007). Indeed, when employees fear disciplinary actions, they will refrain from responding to the leader with deviant acts (Aquino, Tripp, \& Bies, 2006; Tepper, Carr, Breaux, Geider, Hu, \& Hua, 2009).

Nevertheless, more work is needed to understand other conditions that may influence employees' reactions. Therefore, future research should take other factors into account that may determine if the leader's behavior is tolerated. Organizational, work-group, and intrapersonal factors may influence employees' reactions. For example, employees' reactions might depend on their psychological safety. When psychological safety is high, employees are assured that the other members of the team "will not embarrass, reject, or punish someone for speaking up" (Edmondson, 1999, p. 354). Without safety, employees may fear that retaliating against the leader will lead to being ridiculed or penalized (Stouten et al., in press). In contrast, when psychological safety is high, employees feel able to speak up about errors and mistakes (Edmondson, 2004). Therefore, we suggest that when employees experience psychological safety, they are more willing to take the risk to retaliate against the leader. Moreover, high ethical climates might create environments where employees feel more psychologically safe to report self-serving behavior, because such behaviors are disciplined high ethical climates (Mayer et al., 2015). In sum, we suggest that future research explores the existence of additional boundary conditions for employees' reactions towards a selfserving leader.

\section{Practical Implications}


Leaders, more often than employees, put themselves first and feel entitled to use the Cremer, \& van Dijk, 2005). The present research demonstrates that employees have stronger reactions to this behavior when the ethical climate is high rather than low. More specifically, employees show lower levels of trust and higher levels of desire to retaliate and of supervisordirected deviance to a leader who shows self-serving behavior (compared to a leader who shows less self-serving behaviors), and this relationship is stronger in a high ethical climate. Organizations should become aware of the positive (negative) impact of (un)ethical climates on the behavior of organizational members. For example, previous research shows that ethical climates lead to higher levels of ethical reasoning and more ethical decision making (Martin \& Cullen, 2006). Indeed, an ethical climate might boost employees to take personal responsibility and report wrongdoing to management (Bazerman \& Tenbrunsel, 2011). Therefore, organizations are advised to create and maintain an ethical climate, which gives employees guidelines for how to behave. Organizations may emphasize the benefits and value of behaving in an ethical way. For example, one should not only define success by the results, but also by the way these results are obtained (Mayer et al., 2015). Indeed, overvaluing outcomes might result in accepting unethical behaviors when these (short-term) outcomes are good (Bazerman \& Tenbrunsel, 2011). Therefore, organizations are recommended to reward ethical behavior and discourage unethical behavior. Moreover, the ethical practices of an organization must also be clearly noticeable so that employees can learn through others' rewards and punishments (Mayer et al., 2010).

Leaders are essential in shaping an ethical climate (e.g., Mayer et al., 2010; Schminke et al., 2005). Therefore, leaders should reflect the desired ethical climate, and they should be actively involved in promoting and maintaining the ethical climate (Appelbaum, Deguire, \& 
Lay, 2005; Sims, 1992). Moreover, leaders are advised to improve their relationships with employees and try to create an atmosphere of trust in their work group (Ding et al., 2012).

Given the negative consequences of self-serving leader behavior, organizations should try to prevent their occurrence because employees often do not have sufficient power to stop the leader's behavior (Near \& Miceli, 1986; Tepper et al., 2009). Moreover, because leaders act as role models for their employees, when a leader is acting self-servingly, employees might also be tempted to act in the same way (Brown \& Treviño, 2006; Padilla et al., 2007). Organizations can create prevention trainings to avoid self-serving behaviors. For example, organizations could organize training programs to explain to leaders the potential negative influences that self-serving behaviors can have on their employees and the organization. These training programs should train leaders to become good role models and learn them that they should also focus on - and give more consideration to - their employees.

Organizations are also recommended to adopt a zero-tolerance policy when it comes to self-serving leader behavior (Decoster et al., 2014a). Ensuring that leaders are held accountable for their decisions will decrease the likelihood of self-serving behavior. This can be done by establishing transparency and visibility of the leader's decisions. For example, leaders should be asked to publicly justify their financial decisions (Decoster et al., 2014b). Moreover, it is important to nip self-serving behaviors in the bud before they get the chance to exert a social influence effect (Robinson \& O'Leary-Kelly, 1998). If organizations succeed in quickly redirecting the leaders' unwanted self-serving behavior into more desired ethical behaviors, they may limit the negative consequences. Finally, organizations may discourage self-serving behavior by taking self-serving behavior as one of the indicators for evaluating and rewarding the leader's performance.

\section{Limitations and Suggestions for Future Research}


Despite the theoretical and practical contributions of our research, it also has certain limitations. First, the cross-sectional design of Study 2 did not allow us to draw causal conclusions regarding the direction of the observed effects. Therefore, we cannot rule out that a higher desire for retaliation or supervisor-directed deviance made employees rate their leaders as more self-serving. However, the findings of Study 2 are consistent with the scenario study (Study 1), which provided evidence for the causal direction of our hypotheses. Moreover, the results of our study are consistent with previous studies that showed that selfserving types of leader behavior are an important antecedent of employees' deviance (e.g., Schmid et al., 2017). Therefore, we feel confident in the proposed directions of the relationships.

A second limitation pertains to the possibility of common-method bias. Even though we used a multi-source design, it is still possible that common-method bias exists. For example, concerns about social desirability might have played a role. Nevertheless, we took care to signal that responses would be treated with anonymity and would never be traced back to respondents. Moreover, in our studies common-method bias is of a lesser concern because our studies are designed to test interaction effects (Podsakoff, MacKenzie, \& Podsakoff, 2012). Indeed, interaction effects are less likely to be artifacts of common-method bias (Siemsen, Roth, \& Olivera, 2010; Evans, 1985). In all, given that we used a design that has been documented to reduce common-method bias and we took the above measures, we feel confident that common-method bias is of lesser concern.

Third, the experimental design of Study 1 can elicit concerns about the external validity. That is, in this study participants imagined that they were confronted with a selfserving leader, which means they did not engage in real interactions with the leader. The scenario experiment also took place for a limited time, in contrast to organizational settings where employees are confronted with their leader over longer periods of time. However, 
because our multi-source field study (Study 2) showed a consistent pattern in the results, we term effects of self-serving leader behavior on employees' supervisor-directed deviance, to explore whether employees' reactions become stronger depending on how long employees are confronted with their leader. Indeed, as self-serving leader behaviors are less hostile than, for example, abusive supervision, it may take more time before these behaviors produce their negative effect on employees and the organization (Schmid et al., 2017).

We already mentioned that whether the leader's behavior actually harms employees or not is theoretically orthogonal to the definition of self-serving leader behavior (de Dreu \& Nauta, 2009; Williams, 2014). Indeed, the primary intention of the leader is to benefit him/herself. This means that self-serving leadership is self-directed without necessarily targeting employees or the organization. This is where self-serving leader behaviors differ from exploitative leadership, where the leader shows employee-directed behaviors such as using employees for personal gain or taking credit for employees' work (Schmid et al., 2017). Indeed, exploitative leadership targets employees directly by exploiting them (Schmid et al., 2017; Schmid, Verdorfer, \& Peus, 2018). In contrast, self-serving leaders only focus on themselves, and the outcomes for employees may be an (un)fortunate consequence of these behaviors. In theory, employees' outcomes may be negative, neutral or even positive. However, in general, self-interested leader behavior is at the expense of the employees and the organization (DeCelles, DeRue, Margolis, \& Ceranic, 2012; Haynes et al., 2015; Schyns \& Schilling, 2013). Even if the direct and immediate impact of the self-serving leader on his/her employees is positive, the long-term impact on employees and organization is expected to be negative (Thoroughgood et al., 2012; Williams, 2014). Previous research already shows that employees evaluate leader's self-serving behavior as less severe if they perceive it as less harmful to themselves (Decoster et al., 2014b). This research suggests that employees' 
judgment of their leader's self-serving behavior is bounded by, or even biased by, the

(un)favorable outcomes the behavior creates for the employees. Future research should therefore examine more in depth how employee reactions to a self-serving leader differ depending on whether employees are harmed, not impacted, or even benefit from the leader's behavior. In sum, more research is needed to more precisely characterize what drives employees' reactions towards leaders' self-interested behavior.

Finally, we also suggest that future studies might measure ethical climate not only at the psychological level (individual perceptions of the work environment), but also at an aggregate work-unit level (collective perceptions of the work environment) (Kuenzi \& Schminke, 2009). Until now, most of the research has focused on the psychological climate level (Newman, Round, Bhattacharya, \& Roy, 2017). Future research could also focus on the unit level and use a multilevel approach and aggregate multiple employees for each leader. Indeed, ethical climate is typically conceptualized at the unit level, and therefore it would be beneficial to also measure it at this level to accomplish a more thorough understanding of how self-serving leader behavior impacts both the individual and team level (see also Markham, 2010).

\section{Conclusion}

Leaders sometimes act in a self-serving way. The present research shows that even though self-serving leadership has implications for employees in general, employees do not always respond against their leaders' behavior. Particularly, when employees do not perceive an ethical climate they refrain to react. Yet, when employees perceive their work environment to contain important ethical elements (i.e., a high ethical climate), ironically, they react with retaliatory measures. Hence, even in ethical environments, employees engage in deviant behavior in order to signal their disapproval towards self-serving leaders. 


\section{Ethical Approval}

1

All procedures performed in studies involving human participants were in accordance with the ethical standards of the institutional and/or national research committee and with the 1964 Helsinki declaration and its later amendments or comparable ethical standards. 
Adams, J. S. (1965). Inequity in social exchange. In L. Berkowitz (Ed.), Advances in experimental social psychology (Vol. 2, pp. 267-299). New York, NY: Academic Press.

Aiken, L.S, \& West, S.G. (1991). Multiple regressions: testing and interpreting interactions. New York: Sage Publications.

Aquino, K., \& Thau, S. (2009). Workplace victimization: Aggression from the target's perspective. Annual Review of Psychology, 60, 717-741.

Aquino, K., Tripp, T. M., \& Bies, R. J. (2006). Getting even or moving on? Power, procedural justice, and types of offense as predictors of revenge, forgiveness, reconciliation, and avoidance in organizations. Journal of Applied Psychology, 91, 653-668.

Arbogast, S. V. (2008). Resisting Corporate Corruption: Lessons in Practical Ethics from the Enron Wreckage. M \& M Scrivener Press, Salem, MA.

Aryee, S., Chen, Z. X., Sun, L. Y., \& Debrah, Y. A. (2007). Antecedents and outcomes of abusive supervision: Test of a trickle-down model. Journal of Applied Psychology, 92, 191-201.

Barclay, L. J., Whiteside, D. B., \& Aquino, K. (2014). To Avenge or Not to Avenge? Exploring the Interactive Effects of Moral Identity and the Negative Reciprocity Norm. Journal of Business Ethics, 121, 15-28.

Becker, T. E. (2005). Potential problems in the statistical control of variables in organizational research: A qualitative analysis with recommendations. Organizational Research Methods, 8, 274-289.

Berry, C. M., Carpenter, N. C., \& Barratt, C. L. (2012). Do Other-Reports of Counterproductive Work Behavior Provide an Incremental Contribution Over SelfReports? A Meta-Analytic Comparison. Journal of Applied Psychology, 97, 613-636. 
Bies, R. J. (2013). The delivery of bad news in organizations: a framework for analysis. Journal of Management, 39, 136 - 162.

Bies, R. J., \& Tripp, T. M. (2001). A passion for justice: The rationality and morality of revenge. In R. Cropanzano (Ed.), Justice in the workplace: From theory to practice. Mahwah, NJ: Erlbaum.

Bies, R. J., \& Tripp, T. M. (1996). Beyond distrust: Getting even and the need for revenge. In R. M. Kramer \& T. R. Tyler (Eds.), Trust in organizations (pp. 246-260). Thousand Oaks, CA: Sage.

Blau, P. (1964). Exchange and power in social life. New York: Wiley.

Brockner, J., Siegel, P. A., Daly, J. P., Tyler, T., \& Martin, C. (1997). When trust matters: The moderating effect of outcome favorability. Administrative Science Quarterly, 42, $558-583$.

Brown, M. E., \& Treviño, L. K. (2006). Ethical leadership: A review and future directions. Leadership Quarterly, 17, 595-616.

Brown, M. E., Treviño, L. K., \& Harrison, D. A. (2005). Ethical leadership: A social learning perspective for construct development and testing. Organizational Behavior and Human Decision Processes, 97, 117-134.

Burgoon, J. K. (1993). Interpersonal expectations, expectancy violations, and emotional communication. Journal of Language and Social Psychology, 12,30-48.

Burke, C. S., Sims, D. E., Lazzara, E. H., \& Salas, E. (2007). Trust in leadership: A multilevel review and integration. Leadership Quarterly, 18, 606-632.

Burris, E. R., Detert, J. R., \& Chiaburu, D. S. (2008). Quitting before leaving: The mediating effects of psychological attachment and detachment on voice. Journal of Applied Psychology, 93, 912-922. 
Camps, J., Decoster, S., \& Stouten, J. (2012). My share is fair, so I don't care: The moderating role of distributive justice in the perception of leaders' self-serving behavior. Journal of Personnel Psychology, 11, 49-59.

Carlsmith, K. 2002. Why do we punish? Deterrence and just deserts as motives for punishment. Journal of Personality and Social Psychology, 83, 284-299.

Carlson, K. D., \& Wu, J. P. (2012). The illusion of statistical control: Control variable practice in management research. Organizational Research Methods, 15, 413-435.

Chen, C.-C., Chen, M., \& Liu, Y.-C. (2013). Negative affectivity and workplace deviance: the moderating role of ethical climate. International Journal of Human Resource Management, 24, 2894-2910.

Cialdini, R. B., Reno, R. R., \& Kallgren, C. A. (1990). A focus theory of normative conduct: Recycling the concept of norms to reduce littering in public places. Journal of Personality and Social Psychology, 58, 1015-1026.

Colquitt, J. A., Scott, B. A., \& LePine, J. A. (2007). Trust, trustworthiness, and trust propensity: A meta-analytic test of their unique relationships with risk taking and job performance. Journal of Applied Psychology, 92, 909-927.

Cullen, J. B., Parboteeah, K. P., \& Victor, B. (2003). The effects of ethical climates on organizational commitment: A two-study analysis. Journal of Business Ethics, 46, $127-141$.

Decoster, S., Stouten, J., Camps, J., Tripp, T. (2014a). The Role of Employees 'OCB and Leaders' Hindrance Stress in the Emergence of Self-Serving Leadership. Leadership Quarterly, 25, 647-659.

Decoster, S., Stouten, J., \& Tripp, T. M. (2014b). Followers' reactions to self-serving leaders: The influence of the organization's budget policy. American Journal of Business, 29, 202-222. 
De Cremer, D., \& Van Dijk, E. (2005). When and why leaders put themselves first: Leader behaviour in resource allocations as a function of feeling entitled. European Journal of Social Psychology, 35, 553-563.

De Cremer, D., van Dijke, M., Schminke, M., De Schutter, L., \& Stouten, J. (2018). The trickle-down effects of perceived trustworthiness on subordinate performance. Journal of Applied Psychology, 103, 1335-1357.

de Dreu, C. K. W., \& Nauta, A. (2009). Self-interest and other-orientation in organizational behavior: Implications for job performance, prosocial behavior, and personal initiative. Journal of Applied Psychology, 94, 913-926.

Ding, X. Q., Tian, K., Yang, C. S., \& Gong, S. F. (2012). Abusive supervision and LMX Leaders' emotional intelligence as antecedent variable and trust as consequence variable. Chinese Management Studies, 6, 258-271.

Dirks, K. T., \& Ferrin, D. L. (2002). Trust in leadership: Meta-analytic findings and implications for research and practice. Journal of Applied Psychology, 87, 611-628.

Duffy, M. K., \& Ferrier, W. J. (2003). Birds of a feather...? How supervisor-subordinate dissimilarity moderates the influence of supervisor behaviors on workplace attitudes. Group \& Organization Management, 28, 217-248.

Echambadi, R., \& Hess, J. D. (2007). Mean-centering does not alleviate collinearity problems in moderated multiple regression models. Marketing Science, 26, 438-445.

Edmondson, A. C. (2004). Learning from failure in health care: Frequent opportunities, pervasive barriers. Quality and Safety in Health Care, 13, 113-119.

Eisenberger, R., Stinglhamber, F., Vandenberghe, C., Sucharski, I. L., \& Rhoades, L. (2002). Perceived supervisor support: Contributions to perceived organizational support and employee retention. Journal of Applied Psychology, 87, 565-573. 
El Akremi, A., Vandenberghe, C., \& Camerman, J. (2010). The role of justice and social exchange relationships in workplace deviance: Test of a mediated model. Human Relations, 63, 1687-1717.

Evans, M. G. (1985). A monte-carlo study of the effects of correlated method variance in moderated multiple-regression analysis. Organizational Behavior and Human Decision Processes, 36, 305-323.

Fox, S., Spector, P. E., \& Miles, D. (2001). Counterproductive work behavior (CWB) in response to job stressors and organizational justice: Some mediator and moderator tests for autonomy and emotions. Journal of Vocational Behavior, 59, 291-309.

Gouldner, A. W. (1960). The norm of reciprocity - A preliminary statement. American Sociological Review, 25, 161-178.

Greenbaum, R. L., Mawritz, M. B., Mayer, D. M., \& Priesemuth, M. (2013). To act out, to withdraw, or to constructively resist? Employee reactions to supervisor abuse of customers and the moderating role of employee moral identity. Human Relations, 66, 925-950.

Greenberg, J., \& Folger, R. (1988). Controversial issues in social research methods. New York: Springer-Verlag.

Greenberg, J., \& Tomlinson, E. C. (2004). Situated experiments in organizations: Transplanting the lab to the field. Journal of Management, 30, 703-724.

Gregoire, Y., \& Fisher, R. J. (2006). The effects of relationship quality on customer retaliation. Marketing Letters, 17, 31-46.

Hayes, A. F. (2018). Introduction to mediation, moderation, and conditional process analysis: A regression-based perspective (2nd ed.). New York, NY: The Guilford Press. 
Hershcovis, M. S., Turner, N., Barling, J., Arnold, K. A., Dupre, K. E., Inness, M., et al. (2007). Predicting workplace aggression: A meta-analysis. Journal of Applied Psychology, 92(1), 228-238.

Inness, M., Barling, J., \& Tumer, N. (2005). Understanding supervisor-targeted aggression: A within-person, between-jobs design. Journal of Applied Psychology, 90, 731-739.

Jones, D. A. (2009). Getting even with one's supervisor and one's organization: relationships among types of injustice, desires for revenge, and counterproductive work behaviors. Journal of Organizational Behavior, 30, 525-542.

Kellerman, B. (2004). Bad leadership: What it is, how it happens, why it matters. Boston, MA: Harvard Business School Press.

Kelloway, E. K., Francis, L., Prosser, M., \& Cameron, J. E. (2010). Counterproductive work behavior as protest. Human Resource Management Review, 20, 18-25.

Keltner, D., Gruenfeld, D.H., \& Anderson, C. (2003). Power, approach, and inhibition. Psychological Review, 110, 265-284.

Klaussner, S. (2014). Engulfed in the abyss: The emergence of abusive supervision as an escalating process of supervisor-subordinate interaction. Human Relations, 67, 311332.

Konovsky, M. A., \& Pugh, S. D. (1994). Citizenship behavior and social-exchange. Academy of Management Journal, 37, 656-669.

Korsgaard, M. A., Schweiger, D. M., \& Sapienza, H. J. (1995). Building commitment, attachment, and trust in strategic decision-making teams: The role of procedural justice. Academy of Management Journal, 38, 60-84.

Kromrey, J. D., \& Foster-Johnson, L. (1998). Mean centering in moderated multiple regression: Much ado about nothing. Educational and Psychological Measurement, $58,42-67$. 
Kuenzi, M., \& Schminke, M. (2009). Assembling fragments into a lens: A review, critique, and proposed research agenda for the organizational work climate literature. Journal of Management, 35, 634-717.

Lee, K., \& Allen, N. J. (2002). Organizational citizenship behavior and workplace deviance: The role of affect and cognitions. Journal of Applied Psychology, 87, 131-142.

Leventhal, G. S. (1980). What should be done with equity theory? New approaches to the study of fairness in social relationships. In K. Gergen, M. Greenberg, \& R. Willis

(Eds.), Social exchange: Advances in theory and research (pp. 27-55). New York, NY: Plenum Press.

Lewicki, R., \& Bunker, B. (1996). Developing and maintaining trust in work relationships. In R. Kramer \& T. Tyler (Eds.), Trust in organizations (pp. 114-139). Thousand Oaks, CA: Sage.

Liden, R. C., \& Graen, G. (1980). Generalizability of the vertical dyad linkage model of leadership. Academy of Management Journal, 23, 451-465.

Liu, H., Chiang, J. T.-J., Fehr, R., Xu, M., \& Wang, S. (2017). How do leaders react when treated unfairly? Leader narcissism and self-interested behavior in response to unfair treatment. Journal of Applied Psychology, 102, 1590-1599.

Liu, J., Kwan, H. K., Wu, L. Z., \& Wu, W. K. (2010). Abusive supervision and subordinate supervisor-directed deviance: The moderating role of traditional values and the mediating role of revenge cognitions. Journal of Occupational and Organizational Psychology, 83, 835-856.

Markham, S. E. (2010). Leadership, levels of analysis, and déjà vu: Modest proposals for taxonomy and cladistics coupled with replication and visualization. Leadership Quarterly, 21, 1121-1143. 
Martin, K. D., \& Cullen, J. B. (2006). Continuities and extensions of ethical climate theory: A meta-analytic review. Journal of Business Ethics, 69, 175-194.

Martinko, M. J., Harvey, P., Brees, J. R., \& Mackey, J. (2013). A review of abusive supervision research. Journal of Organizational Behavior, 34(Suppl 1), S120-S137.

Mawritz, M. B., Mayer, D. M., Hoobler, J. M., Wayne, S. J., \& Marinova, S. V. (2012). A trickle-down model of abusive supervision. Personnel Psychology, 65, 325-357.

Mayer, D. M, Kuenzi, M., \& Greenbaum, R. L. (2009). Making ethical climate a mainstream management topic: A review, critique, and prescription for the empirical research on ethical climate. In D. De Cremer (Ed.), Psychological perspectives on ethical behavior and decision making (pp.181-213). Greenwich, CT: Information Age Publishing

Mayer, D. M., Kuenzi, M., \& Greenbaum, R. L. (2015). Creating an ethical organizational environment: How ethical leadership, ethical practices and ethical climate help reduce unethical behavior. Working paper.

Mayer, D. M., Kuenzi, M., \& Greenbaum, R. L. (2010). Examining the link between ethical leadership and employee misconduct: The mediating role of ethical climate. Journal of Business Ethics, 95, 7-16.

Mayer, D. M., Thau, S., Workman, K. M., Van Dijke, M., \& De Cremer, D. (2012). Leader mistreatment, employee hostility, and deviant behaviors: Integrating self-uncertainty and thwarted needs perspectives on deviance. Organizational Behavior and Human Decision Processes, 117, 24-40.

Mayer, R. C., Davis, J. H., \& Schoorman, F. D. (1995). An integrative model of organizational trust. Academy of Management Review, 20(3), 709-734.

Mitchell, M., \& Ambrose, M. (2007). Abusive supervision and workplace deviance and the moderating effects of negative reciprocity beliefs. Journal of Applied Psychology, 92, 1159-1168. 
Mitchell, M. S., \& Ambrose, M. L. (2012). Employees' behavioral reactions to supervisor aggression: An examination of individual and situational factors. Journal of Applied Psychology, 97, 1148-1170.

Newman, A., Round, H., Bhattacharya, S., \& Roy, A. (2017). Ethical climates in organizations: A review and research agenda. Business Ethics Quarterly, 27(4), 475512. doi:10.1017/beq.2017.23

Peng, J., Wang, Z., \& Chen, X. (2018). Does Self-Serving Leadership Hinder Team Creativity? A Moderated Dual-Path Model. Journal of Business Ethics. doi:10.1007/s10551-018-3799-0

Pillai, R., Schriesheim, C. A., \& Williams, E. S. (1999). Fairness perceptions and trust as mediators for transformational and transactional leadership: A two-sample study. Journal of Management, 25, 897-933.

Podsakoff, P. M., MacKenzie, S. B., Lee, J. Y., \& Podsakoff, N. P. (2003). Common method biases in behavioral research: A critical review of the literature and recommended remedies. Journal of Applied Psychology, 88, 879-903.

Podsakoff, P.M., MacKenzie, S.B., Moorman, R.H., \& Fetter, R. (1990). Transformational leader behaviors and their effects on followers' trust in leader, satisfaction, and organizational citizenship behaviors. The Leadership Quarterly, 1, 107-142.

Preacher, K. J., \& Hayes, A. F. (2008). Asymptotic and resampling strategies for assessing and comparing indirect effects in multiple mediator models. Behavior Research Methods, 40, 879-891.

Restubog, S. L. D., Scott, K. L., \& Zagenczyk, T. J. (2011). When distress hits home: The role of contextual factors and psychological distress in predicting employees' responses to abusive supervision. Journal of Applied Psychology, 96, 713-729. 
Robinson, S. L., \& Bennett, R. J. (1995). A typology of deviant workplace behaviors: A multidimensional-scaling study. Academy of Management Journal, 38, 555-572.

Rodgers, M. S., Sauer, S. J., \& Proell, C. A. (2013). The lion's share: The impact of credit expectations and credit allocations on commitment to leaders. Leadership Quarterly, 24, 80-93.

Rousseau, D. M., Sitkin, S. B., Burt, R. S., \& Camerer, C. (1998). Not so different after all: A cross-discipline view of trust. Academy of Management Review, 23, 393-404.

Rubin, R. S., Bommer, W. H., \& Bachrach, D. G. (2010). Operant leadership and employee citizenship: A question of trust? Leadership Quarterly, 21, 400-408.

Rus, D., van Knippenberg, D., \& Wisse, B. (2010a). Leader power and leader self-serving behavior: The role of effective leadership beliefs and performance information. Journal of Experimental Social Psychology, 46, 922-933.

Rus, D., van Knippenberg, D., \& Wisse, B. (2010b). Leader self-definition and leader selfserving behavior. Leadership Quarterly, 21, 509-529.

Rus, D., van Knippenberg, D., \& Wisse, B. (2012). Leader power and self-serving behavior: The Moderating Role of Accountability. Leadership Quarterly, 23, 13-26.

Salancik, G. R., \& Pfeffer, J. (1978). Social information-processing approach to job attitudes and task design. Administrative Science Quarterly, 23, 224-253.

Schmid, E. A., Verdorfer, A. P., \& Peus, C. (2017). Shedding light on leaders' self-interest: theory and measurement of exploitative leadership. Journal of Management. doi: 10.1177/0149206317707810.

Schminke, M., Ambrose, M. L., \& Neubaum, D. O. (2005). The effect of leader moral development on ethical climate and employee attitudes. Organizational Behavior and Human Decision Processes, 97, 135-151. 
Schultz, P. W., Nolan, J., Cialdini, R., Goldstein, N., \& Griskevicius, V. (2007). The constructive, destructive, and reconstructive power of social norms. Psychological Science, 18, 429-434.

Schweitzer, M. E., Hershey, J. C., \& Bradlow, E. T. (2006). Promises and lies: Restoring violated trust. Organizational Behavior and Human Decision Processes, 101, 1-19.

Schwepker, C. H. (2001). Ethical climate's relationship to job satisfaction, organizational commitment, and turnover intention in the salesforce. Journal of Business Research, $54,39-52$.

Schyns, B., \& Schilling, J. (2013). How bad are the effects of bad leaders? A meta-analysis of destructive leadership and its outcomes. The Leadership Quarterly, 24, 138-158.

Shieh, G. (2011). Clarifying the role of mean centering in multicollinearity of interaction effects. British Journal of Mathematical \& Statistical Psychology, 64, 462-477.

Siemsen, E., Roth, A., \& Oliveira, P. (2010). Common method bias in regression models with linear, quadratic, and interaction effects, Organizational Research Methods, 13, 456476.

Simha, A., \& Cullen, J. B. (2012). Ethical climates and their effects on organizational outcomes: Implications from the past and prophecies for the future. Academy of Management Perspectives, 26, 20-34.

Skarlicki, D. R., Barclay, L. J., \& Pugh, S. D. (2008). When explanations for layoffs are not enough: Employer's integrity as a moderator of the relationship between informational justice and retaliation. Journal of Occupational and Organizational Psychology, 81, 123-146.

Spector, P. E., \& Brannick, M. T. (2011). Methodological urban legends: The misuse of statistical control variables. Organizational Research Methods, 14, 287-305. 
Stewart, S. M., Bing, M. N., Davison, H. K., Woehr, D. J., \& McIntyre, M. D. (2009). In the Eyes of the Beholder: A Non-Self-Report Measure of Workplace Deviance. Journal of Applied Psychology, 94, 207-215.

Stouten, J., De Cremer, D., \& Van Dijk, E. (2005). I'm doing the best I can (for myself): Leadership and variance of harvesting in resource dilemmas. Group Dynamics-Theory Research and Practice, 9, 205-211.

Stouten, J., \& Tripp, T. M. (2009). Claiming more than equality: Should leaders ask for forgiveness? The Leadership Quarterly, 20, 287-298.

Stouten, J., Tripp, T. M., Bies, R., \& De Cremer, D. (in press). When something is not right: the value of silence. Academy of Management Perspectives.

Stuckless, N., \& Goranson, R. (1992). The vengeance scale - development of a measure of attitudes toward revenge. Journal of Social Behavior and Personality, 7, 25-42.

Taylor, A. B., MacKinnon, D. P., \& Tein, J. Y. (2008). Tests of the three-path mediated effect. Organizational Research Methods, 11, 241-269.

Tepper, B. J., Carr, J. C., Breaux, D. M., Geider, S., Hu, C. Y., \& Hua, W. (2009). Abusive supervision, intentions to quit, and employees' workplace deviance: A power/dependence analysis. Organizational Behavior and Human Decision Processes, $109,156-167$.

Tepper, B. J., Lambert, L. S., Henle, C. A., Giacalone, R. A., \& Duffy, M. K. (2008). Abusive supervision and subordinates' organization deviance. Journal of Applied Psychology, $93,721-732$

Tepper, B. J., Simon, L., \& Park, H. M. (2017). Abusive supervision. Annual Review of Organizational Psychology and Organizational Behavior, 4, 123-152.

Thau, S., Bennett, R. J., Mitchell, M. S., \& Marrs, M. B. (2009). How management style moderates the relationship between abusive supervision and workplace deviance: An 
uncertainty management theory perspective. Organizational Behavior and Human Decision Processes, 108, 79-92.

Thau, S., Crossley, C., Bennett, R., \& Sczesny, S. (2007). The relationship between trust, attachment, and antisocial work behaviors. Human Relations, 60, 1155-1179.

Trevino, L. K. (1986). Ethical decision making in organizations: A person-situation interactionist model. Academy of Management Review, 11, 601-617.

Victor, B. \& Cullen, J. B. (1987). A theory and measure of ethical climate in organizations. In W. C. Fredrick and L. Preston (Eds.). Research in Corporate Social Performance and Policy (pp. 51-71). London: JAI.

Victor, B. \& Cullen, J. B. (1988). The organizational bases of ethical work climates. Administrative Science Quarterly, 33(1), 101-125.

Wade, J. B., O'Reilly, C. A., \& Pollock, T. G. (2006). Overpaid CEOs and underpaid managers: Fairness and executive compensation. Organization Science, 17, 527-544.

Williams M. J. (2014). Serving the self from the seat of power: goals and threats predict leaders' self-interested behavior. Journal of Management, 40, 1365-1395.

Wimbush, J. C., \& Shepard, J. M. (1994). Toward an understanding of ethical climate: Its relationship to ethical behavior and supervisory influence. Journal of Business Ethics, 13, 637-647.

Wisse, B., \& Rus, D. (2012). Leader self-concept and self-interested behavior: The moderating role of power. Journal of Personnel Psychology, 11, 40-48.

Yukl, G. (1998). Leadership in organizations. Englewood Cliffs, NJ: Prentice-Hall.

Zellars, K. L., Tepper, B. J., \& Duffy, M. K. (2002). Abusive supervision and subordinates' organizational citizenship behavior. Journal of Applied Psychology, 87, 1068-1076. 
Figure 1. The Interaction Between Self-Serving Leadership and Ethical Climate on Trust (Study 2).

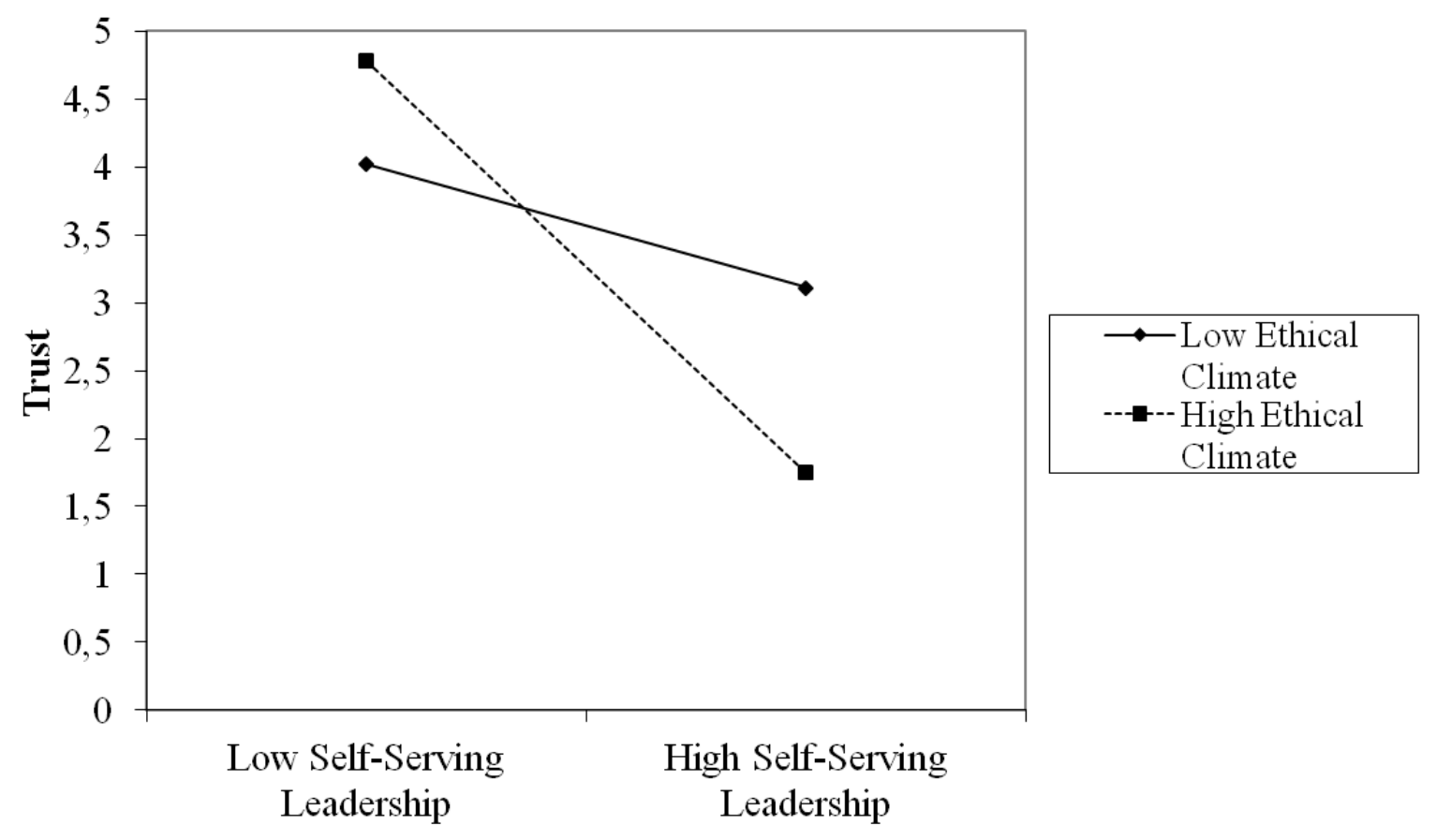


Table 1

The Mediation of the Relation Between Self-Serving Leadership and Desire for Retaliation by Trust for Different Levels of the Ethical Climate in Study 1

\begin{tabular}{|c|c|c|c|c|}
\hline & \multicolumn{4}{|c|}{ Conditional Effects for Ethical Climate } \\
\hline Ethical Climate & $\begin{array}{c}\text { Indirect } \\
\text { Effect }\end{array}$ & $S E$ & $\begin{array}{c}\text { Lower } \\
95 \% \\
\text { bootstrap } \\
\text { CI }\end{array}$ & $\begin{array}{c}\text { Higher } \\
95 \% \\
\text { bootstrap } \\
\text { CI }\end{array}$ \\
\hline Low & .484 & .165 & .201 & .865 \\
\hline High & 1.359 & .310 & .827 & 2.053 \\
\hline
\end{tabular}

Note. $\mathrm{CI}=$ confidence interval. 
Table 2

Means, Standard Deviations, and Intercorrelations for Study 2

\begin{tabular}{llllllllll}
\hline & $M$ & $S D$ & 1. & 2. & 3. & 4. & 5. & 6. & 7. \\
\hline 1. Age & 36.25 & 10.45 & - & & & & & & \\
2. Gender ${ }^{\mathrm{a}}$ & - & - & .01 & - & & & & & \\
3. Job Tenure & 6.46 & 6.36 & $.53^{* *}$ & -.01 & - & & & & \\
4. Self-serving Leadership & 1.61 & .74 & .01 & -.00 & .04 & - & & & \\
5. Ethical Climate & 3.47 & .82 & -.07 & -.09 & -.03 & -.06 & - & & \\
6. Trust & 4.02 & 0.86 & -.00 & .13 & -.03 & $-.59^{* *}$ & .16 & - & \\
7. Desire for Retaliation & 1.31 & .63 & -.15 & -.13 & -.03 & $.43^{* *}$ & -.01 & $-.55^{* *}-$ & - \\
8. Supervisor-Directed Deviance & 1.47 & .66 & $-.19^{*}$ & .03 & -.09 & $.25^{* *}$ & -.19 & $-.51^{* *}$ & $.47^{* *}$ \\
\hline
\end{tabular}

Note. $N=108$.

$* p<.05 * * p<.01$.

a $1=$ female, $2=$ male 
Table 3

Summary of the Hierarchical Regression Analyses of Study 2

\begin{tabular}{|c|c|c|c|c|c|}
\hline & \multicolumn{2}{|c|}{ Trust } & \multicolumn{3}{|c|}{ Desire For Retaliation } \\
\hline Variable & Step 1 & Step 2 & Step 1 & Step 2 & Step 3 \\
\hline Self-Serving Leadership & $-.58 * * *$ & $-.57 * * *$ & $.43 * * *$ & $.42 * * *$ & .18 \\
\hline Ethical Climate & .13 & $.19^{* *}$ & .02 & -.02 & .06 \\
\hline Self-Serving Leadership x Ethical Climate & & $-.33 * * *$ & & $.21 *$ & .07 \\
\hline Trust & & & & & $-.44 * * *$ \\
\hline$\Delta R^{2}$ & & $.10 * * *$ & & $.04 *$ & $.10 * * *$ \\
\hline$R^{2}$ & .37 & .47 & .19 & .23 & .33 \\
\hline Adjusted $R^{2}$ & .35 & .46 & .17 & .21 & .30 \\
\hline$F$ & $30.33 * * *$ & $30.74 * * *$ & $12.09 * * *$ & $10.29 * * *$ & $12.68 * * *$ \\
\hline
\end{tabular}

Note. Standardized beta coefficients are reported.

$* p<.05 ; * * p<.01 ; * * * p<.001$. 
Table 3 (continued)

Summary of the Hierarchical Regression Analyses of Study 2

Note. Standardized beta coefficients are reported.

$* p<.05 ; * * p<.01 ; * * * p<.001$. 
Table 4

The Mediation of the Relation Between Self-Serving Leadership and Desire for Retaliation and Supervisor-Directed Deviance by Trust (Study 2)

\begin{tabular}{lcccc}
\hline & $\begin{array}{c}\text { Estimate of } \\
\text { the Indirect } \\
\text { Effect }\end{array}$ & $\begin{array}{c}\text { Standard } \\
\text { Error }\end{array}$ & $\begin{array}{c}\text { Lower 95\% } \\
\text { Bootstrap CI }\end{array}$ & $\begin{array}{c}\text { Higher 95\% } \\
\text { Bootstrap CI }\end{array}$ \\
\hline Desire for Retaliation & .224 & .097 & .086 & .494 \\
Supervisor-Directed Deviance & .287 & .081 & .168 & .511 \\
\hline
\end{tabular}

Note. $\mathrm{CI}=$ confidence interval. 
Table 5

The Mediation of the Relation between Self-Serving Leadership and Desire for Retaliation and Supervisor-Directed Deviance by Trust for Different Levels of the Ethical Climate (Study 2)

\begin{tabular}{|c|c|c|c|c|c|}
\hline & & \multicolumn{4}{|c|}{ Conditional Effects for Ethical Climate } \\
\hline & Ethical Climate & $\begin{array}{l}\text { Indirect } \\
\text { Effect }\end{array}$ & $S E$ & $\begin{array}{c}\text { Lower } \\
95 \% \\
\text { bootstrap } \\
\text { CI }\end{array}$ & $\begin{array}{c}\text { Higher } \\
95 \% \\
\text { bootstrap } \\
\text { CI }\end{array}$ \\
\hline \multicolumn{6}{|l|}{ Desire for Retaliation } \\
\hline & Low & .101 & .058 & .022 & .272 \\
\hline & Normal & .219 & .090 & .070 & .441 \\
\hline & High & .337 & .139 & .108 & .662 \\
\hline \multicolumn{6}{|l|}{ Supervisor-Directed Deviance } \\
\hline & Low & .130 & .061 & .038 & .282 \\
\hline & Normal & .281 & .071 & .157 & .436 \\
\hline & High & .434 & .109 & .240 & .660 \\
\hline
\end{tabular}

Note. $\mathrm{CI}=$ confidence interval. 
Table 6

The Mediation of the Relation between Self-Serving Leadership and Supervisor-Directed Deviance by Trust and Desire for Retaliation for Different Levels of the Ethical Climate (Study 2)

\begin{tabular}{|c|c|c|c|c|c|}
\hline & \multicolumn{5}{|c|}{ Conditional Effects for Ethical Climate } \\
\hline & Ethical Climate & $\begin{array}{c}\text { Indirect } \\
\text { Effect }\end{array}$ & $S E$ & $\begin{array}{c}\text { Lower } \\
95 \% \\
\text { bootstrap } \\
\text { CI }\end{array}$ & $\begin{array}{c}\text { Higher } \\
95 \% \\
\text { bootstrap } \\
\text { CI }\end{array}$ \\
\hline \multicolumn{6}{|l|}{ Supervisor-Directed Deviance } \\
\hline & Low & .031 & .025 & .000 & .097 \\
\hline & Normal & .068 & .044 & .001 & .172 \\
\hline & High & .104 & .066 & .001 & .260 \\
\hline
\end{tabular}

Note. $\mathrm{CI}=$ confidence interval. 